\title{
THE COMPLEX TOOLING OF CAST IRON FOR LIGHT SECTION CASTINGS
}

\author{
Prof. Dr. M.Sc. Hab. Eng. Stanisław Borkowski
}

Technical University of Czestochowa, Department of Management, Division of Production Engineering, Czestochowa, POLAND

\begin{abstract}
This paper presents results, that were obtained after tooling white cast iron in industrial conditions, using the method of casting modifyed with composite additions. The additions contained components which were more favourable, and also make prime graphitization difficult. It has reached shortening $I^{\text {st }}$ phase of cast iron graphitization, increase of $R_{m}$ and $A_{5}$ tooled materials, as also reasonable lowering of fitted materials hardness. The obtained results were verified using a large slenderness ratio, which in connection with the change of liquid delivery method, it liquified on all lenghts of the microshrinkage and gave off prime carbon.
\end{abstract}




\section{n. I ncur chical vasis ul researcn}

The change in the polish economy from centrally planned economy to a free market economy allows the production of a short series of articles with reference to foundings, where often one furnance is receiving liquid cast iron (often cupola) the production of foundings from chemically diverse composition material and also accomplished proprieties is very difficult. This problem can be partly solved during out of furnance tooling $[1,2,3]$. Ductile cast iron with a ferritic matrix is still a precious constructional material in polish conditions. Its properties are conditioned initially by the chemical composition of a semi - product - of white cast iron. The increased content of carbon and of silicon enlarges the castability of white cast iron (possibility of receiving light section casting foundings), shorten the time of graphitization and is simultaneously a reason of the release of prime graphite, which is liquidating plastic proprieties. Classical modification in this instance does not bring definite results because, among other things, it raises the level of silicon content in cast iron. In this article to solve the problem connected with simultaneous foundings production from ferritic ductile cast iron (black ductile cast iron) at diverse thickness (two lines to forming DISA type) it was decided to carry out cast iron tooling simultaneously with favourable and encunbering components graphitization and silicon calcium - favourable of graphitization. It was decided, so that in addition to composition there would be an organic relationship, as source chemical active carbon - of nucleus of temper carbon. The shortening of graphitization time (economic problem) also favours $\mathrm{Al}_{2} \mathrm{O}_{3}$ arising as a result of the reaction between aluminium and sodium nitrate.

\section{Characteristic of research}

The investigated object was white cast iron, received in a hot-blast cupola, intended on foundings from ductile black cast iron. Identification of the investigative object began from the analysis of its chemical composition. The total influence of the elements $(\mathrm{C}, \mathrm{Si}, \mathrm{Mn}, \mathrm{S})$ on prime graphitization was estimated on the grounds of constant of eutectic isographitization (example 1).

$$
\mathrm{K}_{\mathrm{g}}=\mathrm{C}[\mathrm{Si}-0,2(\mathrm{Mn}-1,7 \mathrm{~S}-0,3)+0,1 \mathrm{P}-1,2 \mathrm{Cr}+0,5 \mathrm{Al}-8 \mathrm{Mg}]
$$

where: $\mathrm{K}_{\mathrm{g}}$ - constant of eutectic graphitization,

$$
\text { C, Si, Mn... - contents of elements in cast iron [4]. }
$$

In mosts cases the value of this constant former was bigger than the critical value, which indicates that the probability of graphite exhalation of primitive graphite in this instance increases. It also shows the large variability value of this constant. From such cast iron it has produced foundings about the large slenderness ratio (fig. 1), which burst during work due to shrinkage porosity or prime graphite exhalations. It was decided that these two failures, which are formed in extreme conditions, were to be eliminated using simultaneous tooling of exit cast iron with graphitizing and stabilizing additions. 

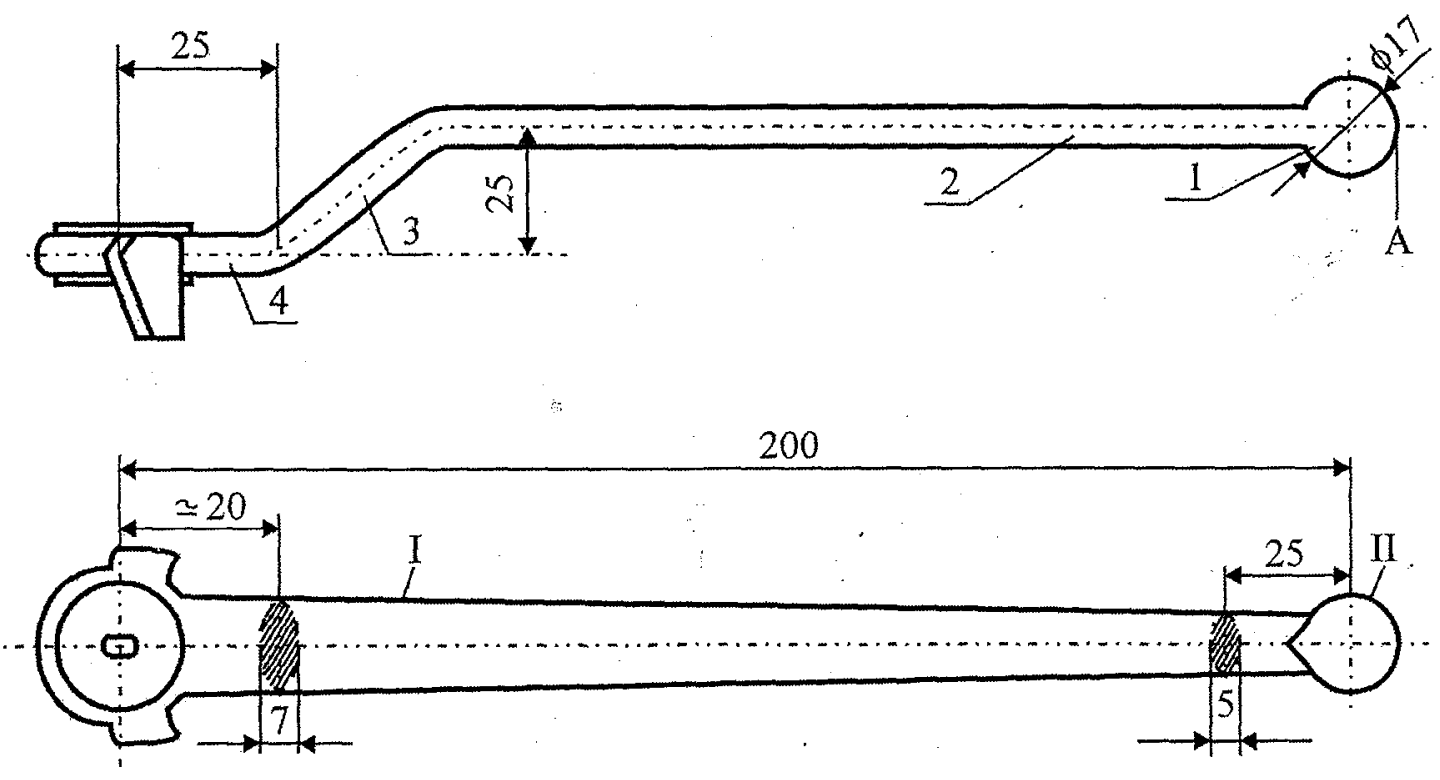

\section{Figure 1. Founding from ductile cast iron with temper carbon about large slenderness ratio}

In work [5] it was decided to solve the problem with using white cast iron tooling with pentocomponent addition (aluminium, ferromanganese, calciumsilicon, nitrate of sodium, dextrin). Assignment exercise of exothermic components (aluminium + nitrate of sodium) was an increase in the number of secondary graphitization centres (it should be shown with shortening of graphizitation time in I phase). Similarly it releases dextrin, which in liquid cast iron temperature undergoes decomposition with the exhalation of chemically active carbon.

Two series of investigations have been carried out varying the chemical constant white cast iron and the quantity of addition ferromanganese. Investigations have also been carried out on the composition rotatabile plan for five variables. Basic level and section of changes recieve properly $X_{1}$ - aluminium $(2,0 ; 0,5), X_{2}$ - ferromanganese $(4 ; 1), X 3$ - calciumsilicon $(1,0 ; 0,5), X_{4}$ - nitrate of $\operatorname{sodium}(2 ; 1), X_{5}-$ dextrin $(1 ; 0,5)$ of gas. For the investigations used ferroalloys were used with composition: ferromanganese $(80 \% \mathrm{Mn}, 1 \% \mathrm{C}, 2 \% \mathrm{Si})$, calciumsilicon $(36 \% \mathrm{Ca}, 58 \% \mathrm{Si}, 5 \% \mathrm{Fe}, 0,4 \% \mathrm{Al})$. Additions to the white cast iron were introduced using the Inmold method. The investigated parameters $(\mathrm{Y})$ were cast iron endurance on extension, hardness, extension in relation to cast irons after first phase and after a full graphitization cycle. It also influenced the additions on $I^{\text {st }}$ graphitization phase time. Obtained results were verified on founding of lever to turning of valves (requirements regarding of material $\mathrm{Rm}>320 \mathrm{MPa}, \mathrm{A}_{5}>12 \%$ ).

\section{Results of laboratory experiments}

The influence of component addition on the endurance of ductile cast iron is represented in figure 2. 
a)

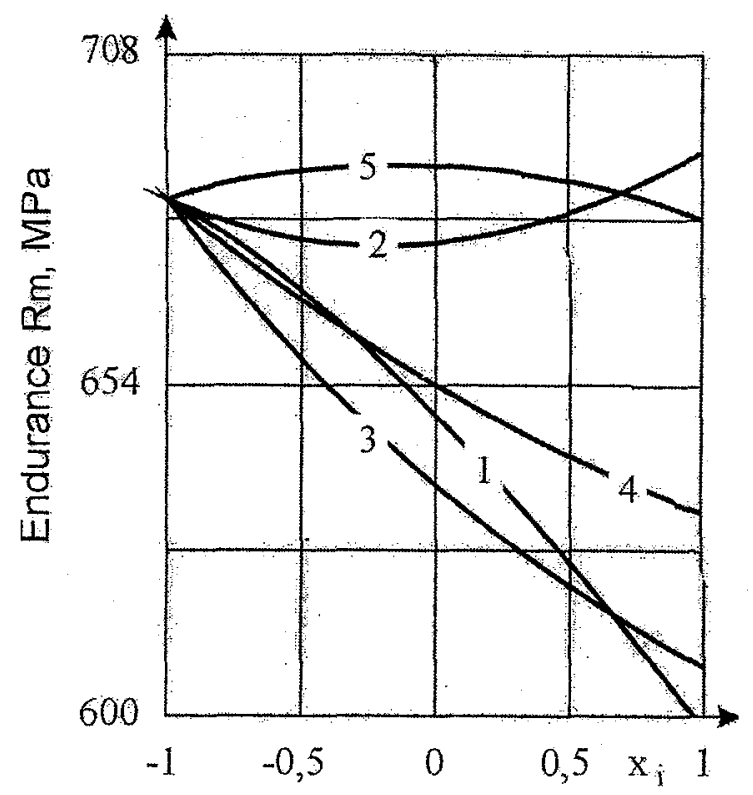

b)

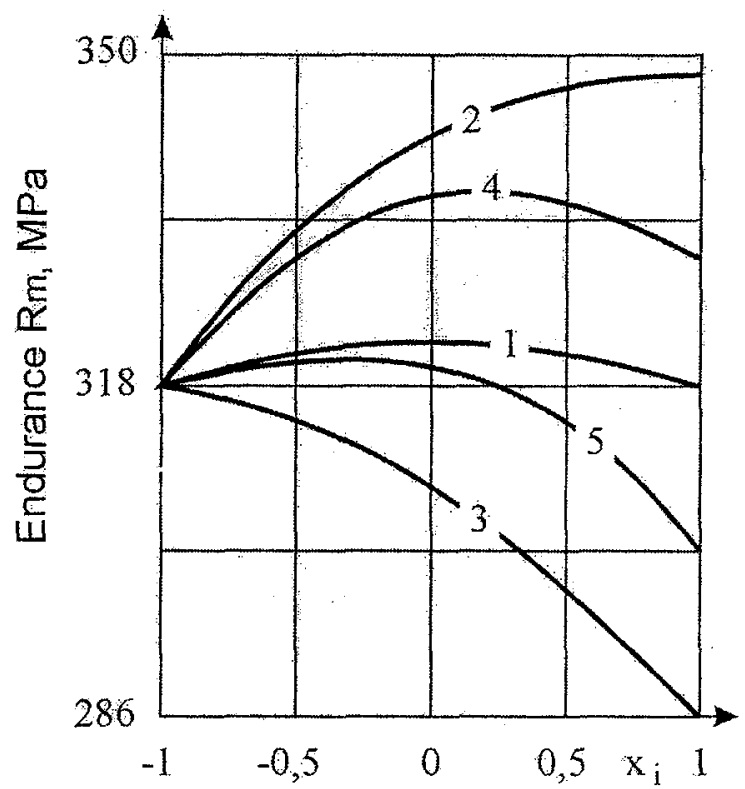

Figure 2. Change of ductile black cast iron endurance after $I^{\text {st }}$ phase (a) and after full graphitization cycle (b) from quantities of addition: 1aluminium, 2-ferromanganium, 3-calciumsilicon, 4-nitrate of sodium, 5-dekstrin

The influence of calciumsilicon and exothermic mixtures appears to be well-founded. Metalographic investigations show that additions of aluminium, ferromanganium, and calciumsilicon enlarge the surface occupied by exhalation of temper carbon. The accuracy of composition of addition confirms. Figure $2 b$ already at $x_{1}=x_{3}=x_{5}=-0,5$ we assure $R_{m}>320 \mathrm{MPa}$. Increasing $R_{m}$ values with height of ferromanganium quantity is conforming with given literature.

The hardness of cast iron (figure 3) after tooling with proposed additions changes in admissible borders. The rise HB ductile cast irons by the addition of can be found with theory and practice. 
a)

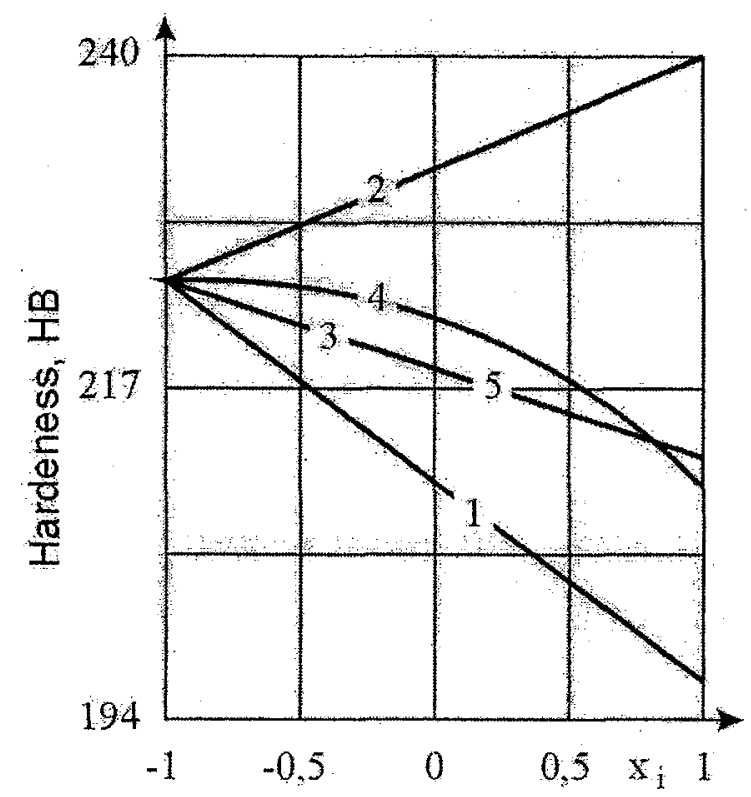

b)

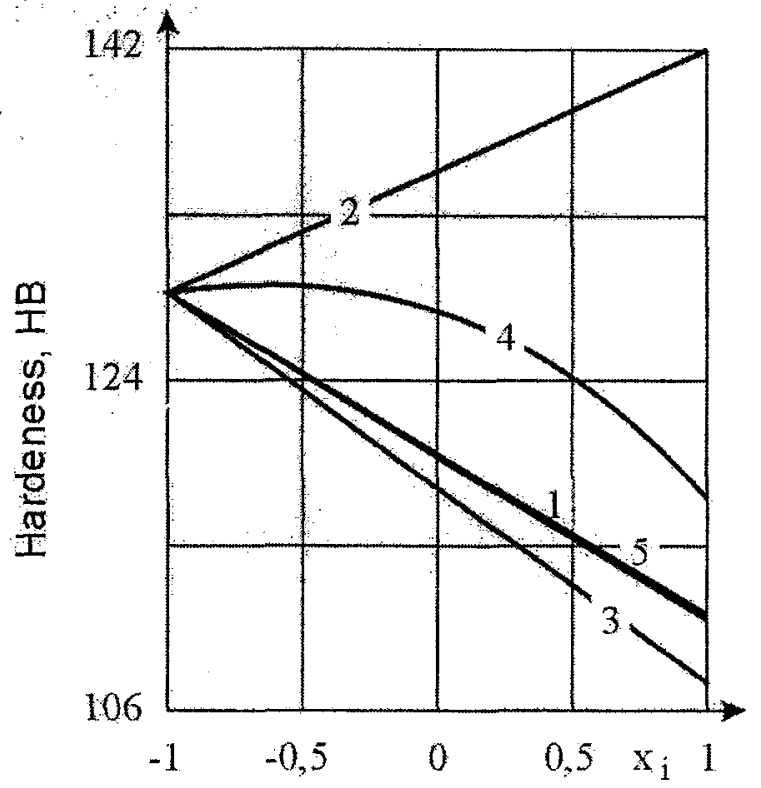

Figure 3. Influence of addition component ductile cast iron hardeness after $I^{\text {st }}$ phase (a) and after full graphitization cycle (b)

The results obtained during the investigations using the $2^{\text {nd }}$ set of properties of cast iron ( $\mathrm{A}_{5}$ ) show (fig. 4), that such compositions of addition exist, which guarantees obtaining the warranted criterion. These compositions can be: $\mathrm{x}_{2}=\mathrm{x}_{3}=\mathrm{x}_{5}=+1, \mathrm{x}_{4}>-0,5$ or $\mathrm{x}_{3}=\mathrm{x}_{4}=\mathrm{x}_{5}=+1, \mathrm{x}_{2}>$ 0 . The second composition satisfies the requirements regarding endurance on the cast iron extension. Although the composition of the additions has already been found, it was decided to quantity the graphitization time in the first tooled white cast iron phase. The obtained results (figure 5) show distinct differences in the influence of each components on the analysed parameter. Analysing the course of changes in graphizitation time under the influence of each additional component shows us, that white cast iron tooling even with the maximum quantity of ferromanganium does not cause a considerable extension of the process - from the time of the $\mathrm{I}^{\text {st }}$ graphitization phase. 


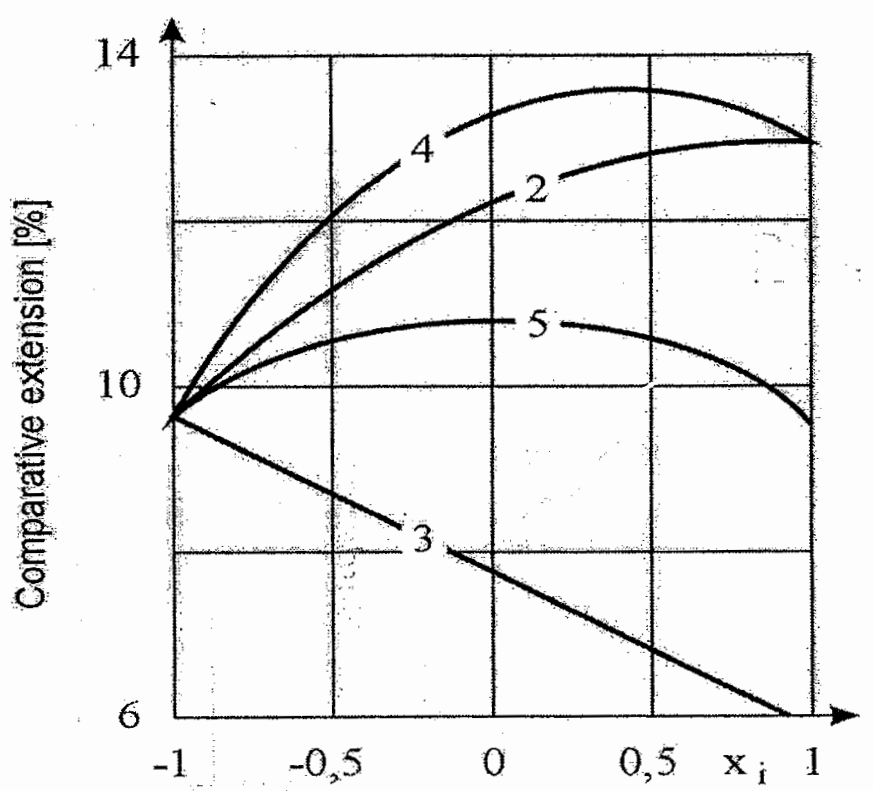

Figure 4. Influence of addition components on relative extension ductile black cast iron

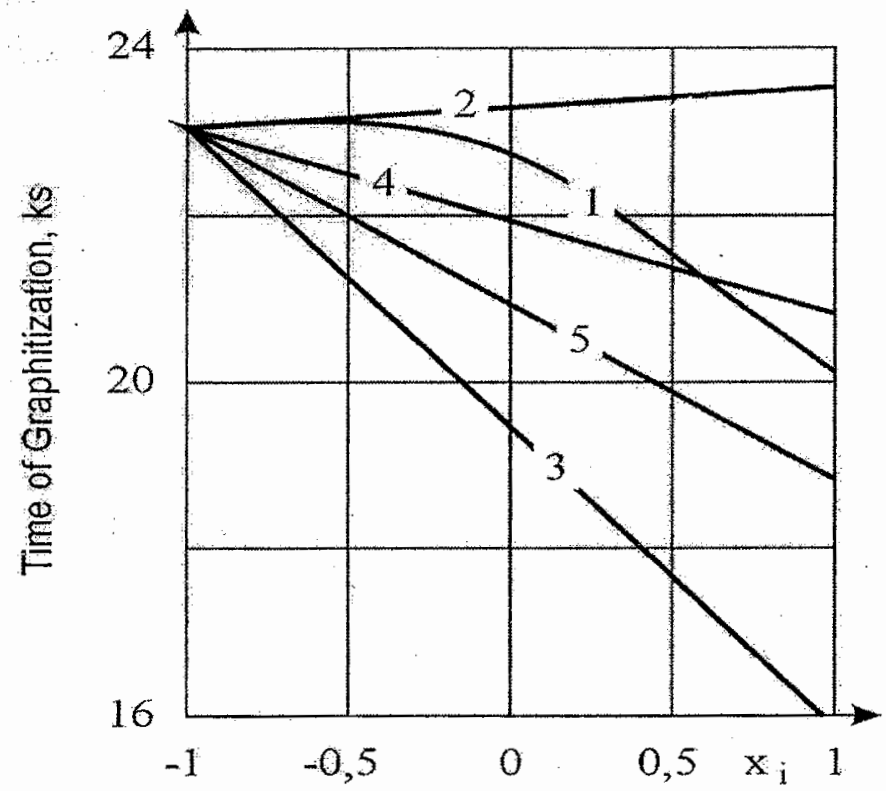

Figure 5. The influence of addition's components to the time of graphitization of the $I^{\text {st }}$ phase. Signature as in figure 2

\section{Practical usage of investigation results}

Following the good results obtained from white cast iron tooling ( $\mathrm{Kg}$ $=4$ ) it was decided to verify them using a slenderness ratio of approximately 20. According to institutional technology metal on lever founding was brought in place appointed: I (see figure 1). Foundings often burst in this place. Founding of lever (figure 1) was divided on several parts, just $15 \mathrm{~mm}$ from point $\mathrm{A}$ was a broken lever and the fracture was investigated. The obtained pattern of a fracture is represented in figure $6 \mathrm{a}$. It is visible from 
this pattern, that microshrinkage stretches a large distance (practically on all lever lengths). In later period, for enlargements metaloabsorbtivity of form, it has brought metal in point II figure 1).

This technology caused greater differentiation of material defects. In part 2 microshrinkage disappeared, however in parts 3 and 4 it was considerably more visible (figure 6b) in comparison with the preceeding variant of the leading metal. Tooling of white cast iron with proposed additions caused, that this manner of leading of metal assures obtaining qualitative materials on lever from plastic cast iron with temper carbon. Microshrinkage appeared only in the $4^{\text {th }}$ parts of the researched founding. It had considerably less defects than in the prime technology. No notification by the control department was given with regard to the quality of the lever $[6,7]$.

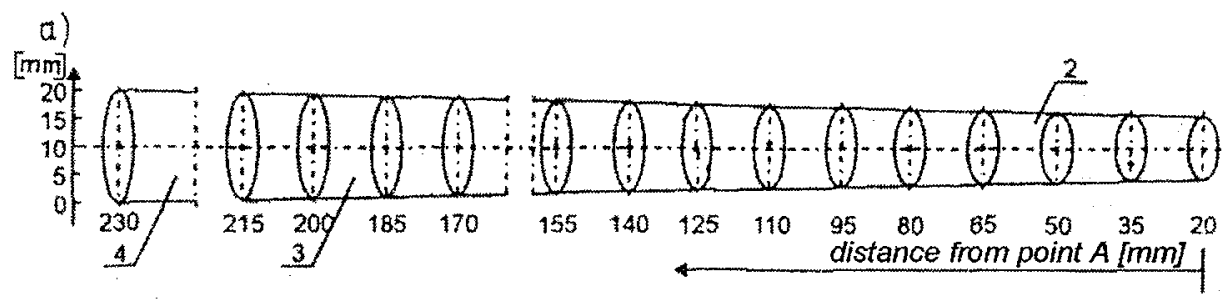

b)

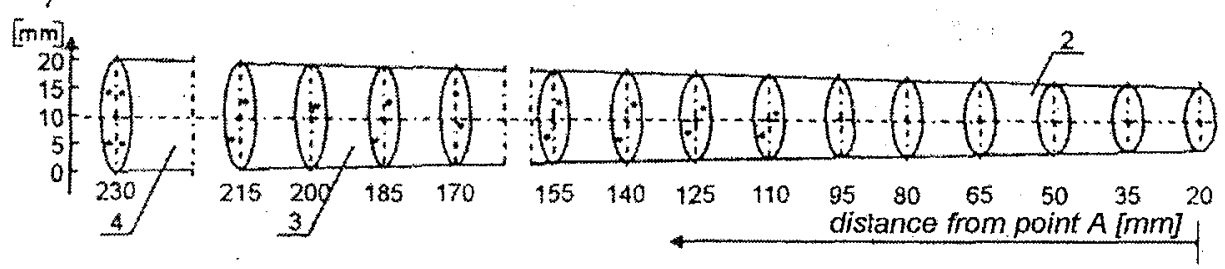

c)

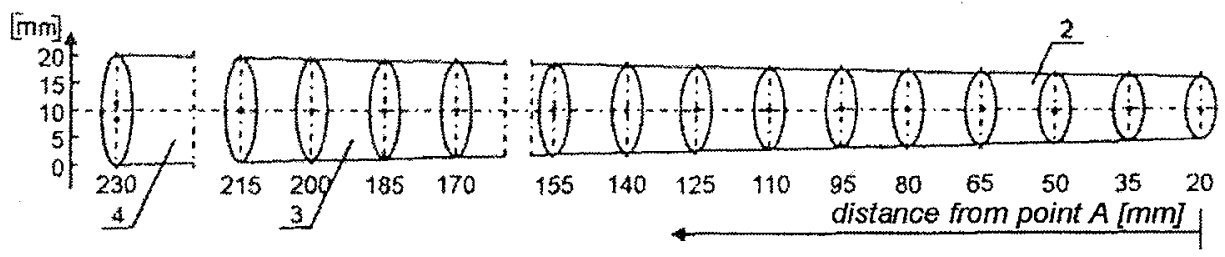

Figure 6. Characterization of structure of lever for different technology: a) prime institutional, b) change of leading of metal place, c) change of leading of metal place in connection with its tooling see figure 1

\section{Conclusions}

This paper has introduced results from an extension of white cast iron tooling and of inlet system projecting. Result of these two series of investigations gives high quality informations from ductile cast iron about its ferritic matrix. The cross section of all lengths of the product did not possess any microshrinkage or exhalation of prime carbon, which disqualifies earlier foundings. In batch of addition has coming in components furthering and encumbering cast iron graphitization and egzothermic mixture. Total result of activity of complicated addition after 


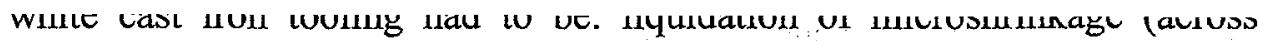
correct selfpowering), liquidation of prime graphite exhalations (presence of component furthering of graphitizations - ferromanganium) and shortening of hightemperature graphitizations time (presence of organic association and egzothermic mixtures). Obtained results in laboratory scale on industrial cast iron it has turned out to be satisfied, however from attention on variables parameters of liquid cast irons it has decided to protect from such a problem by suitable location of inlet. Thanks to the active planning of the research, the obtained results permitted to rate in complex way influence of analyzed parameters and role of each elements.

\section{Literature}

[1]. Warchala T., Borkowski S.: Wytwarzanie zeliwa niskochromowego metoda wdmuchiwania Fe-Si-Cr do kapieli. (Translated from Polish title: Production of the low-chromic cast iron by the Fe-Si-Cr blowing method to the bath. Przeglad Odlewnictwa, 4/1990.

[2]. Borkowski S.: Plánováni zkoušek pri analŷze vlasnosti litiny legovane chromom a titanem. Slevarenstvi, 5/1994.

[3]. Borkowski S.: Sterowanie własciwosciami zeliwa za pomocą dodatku tiomocznika. (Translated from Polish title: Steering properities of cast iron by using the thiourea addition). ArchiwumTechnologii Maszyn i Automatyzacji, Vol. 18/1994.

[4]. Fraś E.: Krystalizacja metali i stopow. (Translated from Polish title: Crystallization of metals and alloys). PWN, Warsaw 1992.

[5]. Borkowski - S.: Sterowanie jakoscia tworzyw odlewniczych na przykładzie zeliwa. (Translated from Polish title: Steering quality of cast materials for example cast iron). WNT, Warsaw 1999.

[6]. Youdelis W.Y., Yang C.S.: Effect of aluminium-soluble elements on grains refinement of aluminium by titanium. Aluminium 19981.

[7]. Flemings M.C.: Solidification Processing. New York, Mc Graw-Hill Book Comp. 1974. 